\title{
Pengaruh Saat Teduh Dan Ibadah Terhadap Pengambilan Keputusan Dalam Memilih Pasangan Hidup
}

\author{
Efi Nurwindayani, Daniel Fajar Panuntun ${ }^{1)^{*}}$ \\ ${ }^{1)}$ Dosen Sekolah Tinggi Teologi Gamaliel \\ ${ }^{*}$ Email: efinurwindayani@stt-gamaliel.ac.id
}

Diterima:01 Agt. 2019 / Direvisi:10 Okt. 2019 / Disetujui:15 Nov. 2019

\begin{abstract}
Abstrak
Fenomena permasalahan dalam keluarga seperti perceraian dan KDRT marak terjadi di Indonesia. Hal ini merupakan permasalahan yang serius. Berdasarkan hal tersebut perlu diadakan tindakan preventif untuk menanggulangi permasalahan tersebut yaitu melalui pengambilan keputusan memilih pasangan hidup. Berdasarkan hal tersebut perlu diadakan penelitian faktor-faktor yang mempengaruhi pengambilan keputusan memilih pasangan hidup.

Pada penelitian ini dilakukan penelitian dengan pendekatan kuantitatif dengan analisis uji regresi tunggal dan uji regresi ganda. Variabel penelitian yaitu $\mathrm{X}_{1}=$ saat teduh, $\mathrm{X}_{2}=$ beribadah di gereja, dan $\mathrm{Y}=$ pengambilan keputusan dalam memilih pasangan hidup. Penelitian dilakukan kepada mahasiswa Kristen se-Surakarta. Dari penelitian ini didadapatkan hasil yaitu pertama, saat teduh memiliki pengaruh yang signifikan terhadap pengambilan keputusan Pasangan Hidup dengan koefisien $\mathrm{Y}=22,446+0,193 \mathrm{X}$. Kedua Beribadah di Gereja memiliki peraguh yang signifikan terhadap pengambilan keputusan Pasangan Hidup dengan koefisien $\mathrm{Y}=15,311+0,442 \mathrm{X}$. Ketiga, Saat Teduh dan Beribadah di Gereja memiliki pengaruh yang signifikan terhadap pengambilan keputusan Pasangan Hidup dengan koefisien $Y=14,329+0,383 X_{1}+0,116 X_{2}$. Kata Kunci: Saat Teduh; Ibadah; Gereja; Pasangan Hidup.
\end{abstract}




\section{Abstract}

The phenemona of family issues such as divorce and domestic violence mostly happen in Indonesia. The issues are severe problems. Based on the problem it is necessary to conduct preventive action to cope with the problems through decision making in choosing life patner. According to the points, it is necesaary to conduct a research about the factors that affect into decicion making to choose life patner.

This research is conducted with the quantitative method using simple and double regresion analysis. The variable of this research were $X_{1}=$ Devotions, $X_{2}=$ worship in a church, dan $Y=$ decision making to choose life patner. The research was conducted among Christian students of universities in Surakarta. The research results such as: (1) Devotions affect into decision-making of life patner with coefficient $Y=22,446+0,193 X$. (2) The worship in church affect into the decision-making of life patner with coefficient $Y=15,311+0,442 X$. (3) The devotions and the worship in a church affect the decision-making of life patner with coefficient $Y=14,329+0,383 X_{1}+0,116 X_{2}$.

Keywords: Quiet Time, Worship, Church, Couple

\section{Pendahuluan}

Kasus-kasus permasalahan hidup keluarga sangat marak terjadi di Indonesia. Berbagai kasus yang terjadi seperti perceraian juga sering terjadi di Indonesia dimana para figur media atau artis juga menjadikan sangat marak. ${ }^{1}$ Selain hal tersebut kasus Kekerasan dalam Rumah Tangga (KDRT) juga menjadi agenda yang cukup marak di Indonesia dan pada akhirnya dampak dari hal tersebut adalah terjadinya perceraian. ${ }^{2}$ Permasalahan hidup berkeluarga menjadi pembahasan yang penting bagi kehidupan berbanga.

Berbagai penelitian mengenai permasalahan kehidupan keluarga banyak diekspos diantaranya adalah: Peranan Polri dalam menangai kasus kekerasan Rumah Tangga di Kota Bau Bau, ${ }^{3}$ Perceraian dini: Studi terhadap putusan

\footnotetext{
${ }^{1}$ Dhony Yusra, "Perceraian dan Akibatnya: Kajian Tentang Pengajuan Permohonan Cerai yang diajukan Pegawai Negeri Sipil”, Lex Jurnalica, Vol 2, No 3, 2005; 22.

${ }^{2}$ Das Salirawati, Antuni WIyarsi, dan Eddy Sulistyowati, "Survei Terhadap Terjadinya Kekerasan dalamRumah Tangga (KDRT) Wanita Karier di Daerah Istimewa Yogyakarta", Jurnal Penelitian Humaniora, Vol 1, No 1, 2013; 62

${ }^{3}$ Jusri, "Peranan Polri dalam menangai kasus kekerasan Rumah Tangga di Kota Bau Bau", Jurnal Sosio Sains, Vol 4, No 9, 2015; 72
} 
pengadilan agama Pekalongan, ${ }^{4}$ Perceraian dan Akibatnya, ${ }^{5}$ Survei Terhadap Terjadinya Kekerasan dalamRumah Tangga (KDRT) Wanita Karier di Daerah Istimewa Yogyakarta, ${ }^{6}$ dan lainnya. Melihat Fenomena tersebut perlu adanya suatu tindakan preventif sebelum terjadinya pernikahan yaitu tahap pemilihan pasangan hidup yang kebanyakan terjadi pada fase perkuliahan atau fase menjadi seorang mahasiswa.

Setiap mahasiswa yang telah percaya kepada Yesus, dipanggil untuk terus bertumbuh dalam kedewasaan iman. Rasul Paulus menulis: Kamu telah menerima Kristus Yesus Tuhan kita. Karena itu hendaklah hidupmu tetap di dalam Dia. Hendaklah kamu berakar di dalam Dia dan dibangun di atas Dia, hendaklah kamu bertambah teguh di dalam iman yang telah diajarkan kepadamu, dan hendaklah hatimu melimpah dengan syukur. ${ }^{7}$ Nasihat ini disampaikan oleh Paulus dalam konteks Jemaat Kolose yang sedang dalam ancaman ajaran sesat. Ajaran sesat tersebut adalah filsafat yang kosong dan palsu menurut ajaran turun temurun dan roh-roh dunia tetapi tidak menurut Kristus. Ajaran tersebut berpotensi menghambat pertumbuhan iman jemaat.

Ada beberapa sarana pertumbuhan iman bagi mahasiswa Kristen diantaranya melalui saat teduh dan ibadah gereja. Mahasiswa perlu membaca, mengerti, memahami, menghayati Alkitab dan melakukannya. Setiap pagi, sebelum melakukan aktivitas, selama kurang lebih lima belas menit mahasiswa perlu bersekutu dengan Firman-Nya. ${ }^{8}$ Inilah yang disebut dengan saat teduh.

Selain itu, mahasiswa juga membutuhkan persekutuan dengan saudara seiman. Salah satu wadah persekutuan tersebut adalah ibadah di gereja. Gereja adalah tempat untuk membangun relasi dengan Allah dan juga dengan saudara seiman.

Melalui saat teduh dan ibadah di gereja, mahasiswa Kristen dapat menemukan kebenaran Firman Tuhan yang berkuasa untuk memimpin mahasiswa dalam mengambil keputusan-keputusan penting dalam hidupnya. Salah satu keputusan penting yang perlu diambil mahasiswa Kristen adalah

${ }^{4}$ Achmad Tubagus Surur dan Hanik Rosyidah, "Perceraian Dini: Studi Terhadap Putusan Pengadilan Agama Pekalongan”, Jurnal Hukum Islam, Vol 14, No 1, 2016; 111.

${ }^{5}$ Dhony Yusra, "Perceraian dan Akibatnya: Kajian Tentang Pengajuan Permohonan Cerai yang diajukan Pegawai Negeri Sipil”, Lex Jurnalica, Vol 2, No 3, 2005; 21.

${ }^{66}$ Das Salirawati, Antuni Wiyarsi, dan Eddy Sulistyowati, "Survei Terhadap Terjadinya Kekerasan dalamRumah Tangga (KDRT) Wanita Karier di Daerah Istimewa Yogyakarta", Jurnal Penelitian Humaniora, Vol 1, No 1, 2013; 62

${ }^{7}$ Kolose 2: 6-7

${ }^{8}$ T, Haryono, Saved By Faith. (Surakarta: Yayasan Gamaliel, 2015), 67-68 
memilih pasangan hidup (kekasih) sebagai tahap persiapan dalam pernikahan. Jika mahasiswa dapat memilih pasangan hidup yang benar, yang sesuai dengan prinsip-prinsip Firman Tuhan maka akan menciptakan surga di bumi. Sebaliknya jika tidak, maka akan menciptakan neraka di bumi. ${ }^{9}$

Berdasarkan Fenomena tersebut perlu dibuat suatu penelitian yang difokuskan untuk mengetahui pengaruh disiplin rohani dalam bersaat teduh dan ibadah di gereja terhadap pengambilan keputusan dalam memilih pasangan hidup sehingga dapat secara preventif mencegah terjadinya "neraka dunia" ataupun masalah-masalah yang terjadi di dalam keluarga nantinya.

Terdapat tiga rumusan masalah dalam penelitian ini yaitu: pertama, apakah saat teduh berpengaruh terhadap pengambilan keputusan dalam memilih pasangan hidup? Kedua, apakah beribadah di gereja berpengaruh terhadap pengabilan keputusan dalam memilih pasangan hidup? Ketiga apakah saat teduh dan ibadah di gereja berpengaruh terhadap pengambilan keputusan dalam memilih pasangan hidup oleh Mahasiswa Kristen Di Surakarta?

Tujuan penelitian ini adalah untuk mengetahui: pertama, pengaruh saat teduh terhadap pengambilan keputusan dalam memilih pasangan hidup. Kedua pengaruh beribadah di gereja terhadap pengambilan keputusan dalam memilih pasangan. Ketiga, pengaruh saat teduh dan ibadah di gereja terhadap pengambilan keputusan dalam memilih pasangan hidup oleh Mahasiswa Kristen Di Surakarta.

Manfaat penelitian ini adalah, pertama, secara teoritis, mengetahui pengaruh saat teduh dan ibadah di gereja terhadap pengambilan keputusan dalam memilih pasangan hidup oleh mahasiswa Kristen di Surakarta. Kedua, secara praktis, sebagai masukkan bagi orang tua dan hamba Tuhan yang melayani mahasiswa agar dapat mengarahkan mereka dalam pertumbuhan rohani melalui saat teduh dan ibadah sehingga dapat memilih pasangan hidup dengan benar.

\section{Metode Penelitian}

Metode penelitian yang digunakan pada penelitian ini menggunakan pendekatan kuantitatif. ${ }^{10}$ Analisis data dilakukan dengan analisis regresi linear

\footnotetext{
${ }^{9}$ Kawangmani, Soleman., "Memilih Pasangan Hidup". Bahan Ceramah Pada Persekutuan Mahasiswa Kristen Surakarta, t.t.

${ }^{10}$ Stevri Indra Lumintang dan Danik Astuti Lumintang, Theologia penelitian dan Penelitian Theologis science-ascience serta metodologinya, (Jakarta: Geneva Insani Indonesia, 2016), 105.
} 
ganda dengan dua prediktor. ${ }^{11}$ Variabel dependen (Y) dalam penelitian ini adalah pengambilan keputusan dalam memilih pasangan hidup, sedangkan variabel independen $1\left(\mathrm{X}_{1}\right)$ adalah saat teduh dan variabel independen $2\left(\mathrm{X}_{2}\right)$ adalah ibadah di gereja.

Definisi istilah operasional pada penelitian ini adalah yaitu pertama, saat teduh adalah kegiatan khusus yang dilakukan oleh orang kristen untuk membaca Firman Tuhan, Memuji nama Tuhan, dan berdoa secara pribadi. Kedua, ibadah di Gereja dapat diartikan sebagai ibadah bersama dimana setiap orang percaya berkumpul bersama-sama untuk berjumpa dengan Allah dan mahami kebenaran Firman Tuhan. Ketiga, pengambilan keputusan dalam memilih pasangan hidup adalah pengambillan keputusan untuk pacaran sebagai dasar awal menuju pernikahan Kristen yang kudus.

Pengumpulan data dengan menggunakan metode kuesioner. Instrumen kuesioner dilakukan pengujian dan validitasi instrumen. ${ }^{12}$ Batasan masalah yang ditetapkan hanya pada permasalahan mengenai pengaruh disiplin rohani dalam bersaat teduh dan beribadah terhadap pengambilan keputusan dalam memilih pasangan hidup oleh Mahasiswa Kristen di Surakarta. Penelitian ini ditujukan untuk mahasiswa Kristen yang ada di Surakarta.

Populasi dalam penelitian ini adalah seluruh Mahasiswa Kristen di Surakarta, jumlah Mahasiswa Kristen di Surakarta adalah sekitar 3000 orang. ${ }^{13}$ Sampel yang diambil dari populasi tersebut yaitu $5 \%$ dari populasi sehingga di dapatkan sampel 150 orang. ${ }^{14}$ Metode sampling yang digunakan adalah metode simple random sampling. ${ }^{15}$ Berdasarkan hal tersebut maka kuesioner akan disebar secara random ke sampling mahasiswa Kristen Surakarta. Data yang didapatkan dari hasil penyebaran angket kuesioner dilakukan proses uji persyaratan yaitu uji normalitas dan homogenitas variansi. ${ }^{16}$

Hipotesis dari penelitian ini adalah pertama, Saat teduh memberikan pengaruh terhadap pengambilan keputusan dalam memilih pasangan hidup. Kedua, beribadah di gereja memberikan pengaruh terhadap pengambilan

${ }^{11}$ Mikha Agus Widiyanto, Statistika: Untuk Penelitian Bidang Teologi, Pendidikan, Agama Kristen, dan Pelayanan Gereja. (Bandung: Kalam Hidup,2014), 271.

${ }^{12}$ Ibid, 289-300

${ }^{13}$ Timotius Haryono, Wawancara dengan pakar: Pembina pelayanan PMK Surakarta, Surakarta, 2019.

${ }^{14}$ William Yount R, Research Deseign and Statistical Analysis in Christian Ministry. (Fort Worth: Southwestern Baptis Teological Swminary, 1999), 7-14.

${ }^{15}$ Mikha Agus Widiyanto, Statistika: Untuk Penelitian Bidang Teologi, Pendidikan, Agama Kristen, dan Pelayanan Gereja. (Bandung: Kalam Hidup, 2014), 95. .

${ }^{16} \mathrm{Ibid}, 123-146$ 
keputusan dalam memilih pasangan hidup. Ketiga,saat teduh dan beribada di gereja memberikan pengaruh terhadap pengambilan keputusan dalam memilih pasangan hidup.

\section{Pembahasan}

\section{Saat Teduh}

Saat teduh adalah waktu khusus yang disediakan seorang anak Tuhan bagi Dia setiap hari. Dalam waktu itu ia bertemu dan bergaul dengan Tuhan, mendengar apa yang dikatakan Tuhan Yesus melalui Firman-Nya dan berbicara kepada-Nya dalam doa. Saat teduh merupakan respon seorang terhadap kerinduan Allah Bapa untuk bersekutu dengan anak-Nya. Persekutuan itu menjadi pergaulan yang indah dengan Tuhan setiap permulaan hari. Bersaat teduh berarti merefleksikan penyerahan diri seorang pada hari itu kepada Tuhan. ${ }^{17}$

Berbagai penelitian dikembangkan untuk mengembangkan saat teduh sehingga semakin pratis dan semakin dapat digunakan oleh berbagai kalangan diantaranya adalah: Perancangan buku saat teduh "Be Strong" sebagai sarana pertumbuhan rohani bagi anak-anak, ${ }^{18}$ Pembuatan aplikasi saat teduh pada mobile device berbasis android, ${ }^{19}$ Pembuatan Aplikasi Saat Teduh "Makanan Rohani" di Windows 8 Metro, ${ }^{20}$ dan lainya. Pengembangan-pengembangan telah dilakukan agar saat teduh dapat di lakukan secara kontinu oleh setiap orang peracaya.

Donald S. Whitney, penulis buku Disiplin Rohani: 10 Pilar Penopang Kehidupan Kristen mengatakan ada banyak alasan alkitabiah yang mendukung diprioritaskannya saat teduh. ${ }^{21}$ Pertama, mengikuti jejak Tuhan Yesus. Alkitab memperlihatkan bahwa Yesus Kristus juga menyendiri untuk bersekutu dengan Allah Bapa. Salah satu contoh terdapat di Injil Markus 1: 35: "pagi-pagi benar, waktu hari masih gelap, Ia bangun dan pergi keluar. Ia pergi ke tempat yang sunyi dan berdoa di sana." Kedua, saat teduh sarana untuk mendengar suara

${ }^{17}$ Haryono, Timotius., "Saat Teduh”, Bahan Ceramah Pada Persekutuan Mahasiswa Kristen Surakarta, t.t

${ }^{18}$ Sri Wahyuning Septarina dan Giovanni, "Perancangan Buku Saat Teduh "Be Strong” Sebagai Sarana Pertumbuhan Rohani Bagi Anak-Anak", Jurnal Ruparupa, Vol 4, No 1, 2015; 1.

${ }^{19}$ Timothy Tiovano Notopuro, Alexander Setiawan, Justinus Andjarwirawan, "Pembuatan Aplikasi Saat Teduh Pada Mobile Device Berbasis Android," Jurnal Infra, Vol 4, No 2, 2016; 1

${ }^{20}$ Enrico Darmawan Handoyo, "Pembuatan Aplikasi Saat Teduh "Makanan Rohani” di Windows 8 Metro".

${ }^{21}$ Donald S. Whitney, 10 Pilar Penopang Kehidupan Kristen. (Malang: Lembaga Literatur Baptis, 1994), 236-252 
Tuhan dengan lebih baik. Ketiga, saat teduh mengungkapkan ibadah kita kepada Tuhan. Keempat, mengungkapkan iman kepada Tuhan. Keempat, saat teduh untuk memohon keselamatan dari Tuhan. Kelima, saat teduh sarana pemulihan secara jasmani dan rohani. Keenam, saat teduh untuk mendapatkan kembali perspektif rohani. Ketujuh, saat teduh sarana untuk mencari kehendak Allah dan kedelapan, sarana untuk mengendalikan lidah.

Cara melakukan saat teduh adalah, pertama, pentingnya disiplin yang tinggi. Banyak orang percaya memulai saat teduh dengan menggebu-gebu dan penuh semangat tapi diakhiri dengan kegagalan. Orang percaya tergoda untuk tidak disiplin. Paulus menulis: seorang prajurit yang sedang berjuang tidak memusingkan dirinya sendiri dengan soal-soal penghidupannya, supaya dengan demikian ia berkenan kepada komandannya. ${ }^{22}$ Modal perjuangan dan disiplin bersaat teduh seperti prajurit akan membuahkan hasil yang maksimal. Kedua, keinginan dan kerinduan yang dalam untuk menikmati Firman Tuhan. Pemazmur berkata: seperti rusa yang merindukan sungai yang berair, demikianlah jiwaku merindukan Engkau, ya Allah (Mazmur 42: 1-2). Kerinduan sedemikian itu timbul karena pertolongan Roh Kudus. Ketiga, menyediakan waktu terbaik yaitu pagi hari. Pada waktu pagi, pikiran masih segar belum dipenuhi kesibukan hari itu. Suasana masih tenang, orang lain belum membuat gangguan, konsentrasi masih mudah. Waktu pagi mencerminkan penghargaan kepada Allah. Keempat, penyelenggaraan saat teduh: mempersiapkan Alkitab, buku catatan dan alat tulis. Berdoalah sambil menyembah Tuhan sebelum merenungkan Firman-Nya. Mulai dengan membaca bagian Alkitab yang digunakan sebagai bahan saat teduh, pahamilah dengan merenungkan setiap bagian Firman Tuhan. Saat membaca bagian Firman Tuhan, tetapkan satu Kitab sampai selesai, mulailah dari Perjanjian Baru. Baca, renungkan dan catat setiap prinsip penting yang didapat. Akhiri saat teduh dengan doa ucapan syukur dan syafaat. Ambil keputusan untuk melaksanakan Firman Tuhan dengan penuh ketaatan.

Hambatan seorang bersaat teduh adalah kemalasan. Hambatan internal ini dikarenakan belum memiliki kesadaran pentingnya saat teduh. Hambatan lainnya adalah tidak memiliki bahan saat teduh, padahal Alkitab adalah materi utama dalam bersaat teduh. Hambatan ketiga adalah banyaknya tugas yang harus diselesaikan sehingga merasa tidak memiliki waktu untuk bersaat teduh.

${ }^{22} 2$ Timotius 2: 4 
Kehidupan saat teduh yang disiplin dan teratur mendatangkan manfaat bagi orang percaya. Pertama, mendapatkan pengenalan yang benar akan Firman Tuhan yang berkuasa menuntun hidup dalam seluruh kebenaran. Kedua, memiliki relasi yang intim dengan Allah sehingga mampu mengambil keputusan yang benar dan tepat. Ketiga, memberi kekuatan dalam menjalani hidup setiap hari dan siap menghadapi masa-masa yang sukar. Keempat, memberi sukacita dan damai sejahtera sehingga kehidupan jasmani dan rohani terpelihara dengan baik.

\section{Ibadah Di Gereja}

Ibadah menurt pengertian Peter Brunner ditunjukan sebagai dualitas ibadah dengan pernyataan bahwa ibadah adalah pelayanan Allah kepada jemaat dan Pelayanan jemaat di hadapan Allah. ${ }^{23}$ Menurut pengertian Hoon Ibadah adalah suatu penyataan Allah kepada manusia melalui Yesus Kristus dan tanggapan manusia tersebut atas Yesus Kristus. Ibadah ini meningkapan keberadaan Allah yang sebenarnya melalui Firman Allah. ${ }^{24}$ Ibadah juga harus dibedakan antara ibadah pribadi/self devotion dan Ibadah bersama. Makna dari ibadah bersama adalah pertemuan atau kedatangan untuk berkumpul. Orang percaya datang untuk berkumpul menemui Allah dan menjumpai sesama. ${ }^{25} \mathrm{Di}$ samping itu, ibadah pun dimengerti sebagai sebuah bentuk liturgi (Yun.: Leitourgia, yang berartiaktivitas yang diperuntukkan untuk kepentingan orang banyak), yaitu sebuah tindakan yang berdampak positif bagi setiap orang yang hadir dalam perkumpulan itu, sehingga berdasarkan berbagai pengertian tersebut Ibadah di Gereja dapat diartikan sebagai Ibadah bersama dimana setiap orang percaya berkumpul bersama-sama untuk berjumpa dengan Allah dan mahami kebenaran Firman Tuhan. ${ }^{26}$

Ibadah sangat penting karena Roh Tuhan memelihara dan membuat bertumbuh dewasa dalam iman menggunakan pembelajaran dalam jemaat. Jemaat akan dapat melihat panggilan Tuhan dan dapat menolong orang lain melalui misi dan pelayanan. Ibadah merupakan cara paling nyata dari Allah untuk menghubungkan orang-orang ke dalam komunitas untuk menggenapi misi

\footnotetext{
${ }^{23}$ Peter Brunner, Worship in the Name of Jesus. Diterjemahkan oleh M.H. Bertram (Louis: Concordia,1968), 125.

${ }^{24}$ Paul W.Hoon, The Integrity of Worship (Nashvile: Abingdon Press, 1971), 77

${ }^{25}$ James F.White, Pengatar Ibadah Kristen, (Jakarta: BPK Gunung Mulia,2017),16-17.

${ }^{26}$ Firman Panjaitan \& Marthin S. Lumingkewas, "Ibadah Jemaat Kristen Kontemporer Abad 21 dan Tinjauan Kritis-Liturgis, Fidei: Jurnal Teologi Sistematikan dan Praktika, Vo. 2, No. 1, Juni 2019, 174-175,
} 
Kristus. ${ }^{27}$ Manfaat ibadah di Gereja akan sangat dirasakan ketika setiap orang percaya bersama-sama dengan saudara seiman lainnya saling menopang, menguatkan dan berkomitmen untuk bertumbuh bersama melalui kebenaran Firman Tuhan dan pujian penyembahan untuk dapat mengetahui panggilan Tuhan dalam hidupnya.

Beribadah di Gereja dapat dilakukan dengan bersama-sama dengan orang percaya untuk berkumpul, memuliakan nama Tuhan, berdoa dan memahami kebenaran Firman Tuhan. Beberapa pola hiudp jemaat yang sehat yang dapat diteapkan di Gereja diantaranya adalah pertama, program pengajaran Firman Tuhan. Kedua, program penyembahan,. Ketiga, program Persekutuan. Keempat, program penginjilan dan pelayanan. ${ }^{28}$ Kontinuitas ibadah di Gereja ahrus terus dilakukan dengan kesadaran penuh untuk memliki sikap bertumbuh ke arah kedewasaan seperti Kristus.

Manfaat beribadah di Gereja akan dirasakan oleh setiap pribadi dimana setiap pribadi dapat bertumbuh secara berkesinambungan dalam komunitas mencapai kedewasaan dalam Kristus. Proses pertumbuhan di dalam Kristus ini secara dinamis akan membawa perubahan-perubahan pada setiap Pribadi. Lima praktisk yang menjadi acuan jemaat yang bertumbuh dapat terlihat dari perubahan: pertama, keramahtamahan yang radikal. Kedua, ibadah jemaat bergairah. Ketiga, berani menerima resiko dari misi dan pelayanan. Keempat, memiliki pertumbuhan iman yang terencana. Kelima, memiliki kemurahan hati yang luar biasa. ${ }^{29}$ Berbagai penelitian dalam ibadahpun juga terut dilakukan untuk meningkatkan manfaat dan memberikan klarifikasi mengenai ibadah diantaranya adalah: Ibadah kontemporer: sebuah analisis reflektif terhadap hadirnya budaya populer dalam Gereja masa kini, ${ }^{30}$ Etnografi komunikasi dalam ibadah sekolah minggu Huria kristen Batak Protestan (HKBP) Maranatha kecamatan Payung Sekaki, ${ }^{31}$ Bahasa lidah dalam Ibadah bersama berdasarkan 1

${ }^{27}$ Robert Schnase, 5 Ciri Jemaat yang Bertumbuh,(Malang:Gandum Mas,2016), 7-8

${ }^{28}$ Nelly P. Thuhumury, Strategi Pemulihan Gereja,(Tangerang, Mantana Publishing Utama,2015),11-22.

${ }^{29}$ Robert Schnase, 5 Ciri Jemaat yang Bertumbuh,(Malang:Gandum Mas,2016), 7.

${ }^{30}$ Yohanis Luni Tumanan, "Ibadah Kontemporer: Sebuah Analisis Reflektif Terhadap Hadirnya Budaya Populer Dalam Gereja Masa Kini," Jurnal Jaffray, Vol 13, No 1, 2015; 35.

${ }^{31}$ Artarty Siringoringo, "Etnografi komunikasi dalam ibadah sekolah minggu Huria kristen Batak Protestan (HKBP) Maranatha kecamatan Payung Sekaki,” Jom Fisip, Vol 2 No 2, 2015; 1. 
Korintus $14,{ }^{32}$ dan lainnya dengan fokus penelitian terhadap ibadah Kristen untuk menjadi semakin lebih bermanfaat.

Hambatan dalam beribadah dapat terjadi karena faktor intern dan faktor ekstern setiap Pribadi. Faktor-faktor ekstern diantaranya seprti terjadinya pembakaran-pembakaran terhadap gereja sehingga kegiatan peribadahan terkendala. ${ }^{33}$ Faktor ekstern lainya yang berpengaruh menghambat seorang untuk beribadah yaitu kehidupan Gereja yang bergeser dari Nilai yang benar sehingga membawa kesenjangan dan kemerosotan. ${ }^{34}$ Faktor-faktor Intern yang mempengaruhi setiap pribadi dapat dilihat dari teori kecerdasan emosinal Goleman yaitu; Kesadaran diri,Pengaturan Diri, Motivasi diri, Empati diri dan ketrampilan sosial. ${ }^{35}$ Pengaruh perkembangan zamanpun juga membuat seseorang pada masa kini memliki kecenderungan untuk menutup diri sehingga tidak dapat percaya kepada orang lain. ${ }^{36}$ Apabila seseorang tidak memiliki aspek-aspek kecerdasan emosi yang benar dan kebutuhan untuk bersekutu dengan saudara seiman maka hal ini akan menghambat dalam setiap kegiatan ibadah di Gereja karena menganggap ibadah tersebut tidak penting.

\section{Memilih Pasangan Hidup}

Lembaga pertama yang diciptakan Allah di Taman Eden adalah lembaga pernikahan. Kitab Kejadian 2 mencatat bahwa Allah yang mengambil insiatif menciptakan Hawa bagi Adam dan mengikat mereka dalam pernikahan kudus. Pernikahan adalah kontrak resmi, sosial dan rohani antara seorang pria dan seorang wanita. Pernikahan merupakan janji ilahi yang dibuat di hadapan Allah. Ini adalah komitmen satu sama lain, ikrar untuk hidup bersama, saling melayani dan tetap setia satu sama lain. Pernikahan juga merupakan cara Allah untuk menunjukkan kasih-Nya bagi kita dan rencana-Nya bagi pernikahan kepada

${ }^{32}$ Urni Hermawaty Sitanggang, "Bahasa lidah dalam Ibadah bersama berdasarkan 1 Korintus 14", Dunamis (Jurnal Teologi dan Pendidikan Kristen), Vol 2, No 1,2017; 45

${ }^{33}$ Raihan Nusyur, "Jurnalisme Damai dalam Pemberitaan PembakaranGereja di Aceh SIngkil pada Harian Waspada,” Jurnal Komunikasi Global, Vol. 6, No 1,2017; 26.

${ }^{34}$ Nelly P. Thuhumury, Strategi Pemulihan Gereja,(Tangerang, Mantana Publishing Utama,,2015),1.

${ }^{35}$ Daniel Goleman, Kecerdasan Emosional untuk mencapai Puncak Prestasi, (Jakarta:PT Gramedia, 2001), 63.

${ }^{36}$ T. Haryono dan Daniel Fajar Panuntun, "Andil Pemuridan Kontekstual Yesus Kepada Petrus Yakobus Dan Yohanes Terhadap Keterbukaan Konseling Mahasiswa Pada Masa Kini”, Jurnal Gamaliel:Teologi Praktika, Vol 1, No 1, 2019;14. 
dunia, dan membantu kita menjadi serupa dengan Doa. ${ }^{37}$ Charles R. Swindoll mengatakan bahwa pernikahan Kristen adalah kesatuan yang murni, tidak terhalang, tidak mementingkan diri sendiri, membahagiakan, yang dinikmati oleh dua orang yang diciptakan untuk satu sama lain. ${ }^{38}$ Begitu sakralnya pernihakan Kristen maka setiap orang percaya harus mempersiapkan dengan baik.

Jonathan A. Trisna dalam bukunya berjudul Pernikahan Kristen mengatakan: jika ingin mempunyai pernikahan seperti yang direncanakan Allah maka harus berdasar pada prinsip Firman Allah (Alkitab). Alkitab adalah pedoman yang paling tepat bagi pernikahan Kristen. ${ }^{39}$

Kejadian Pasal 2: 24 mengatakan: sebab itu seorang laki-laki akan meninggalkan ayahnya dan ibunya dan bersatu dengan istrinya sehingga keduanya menjadi satu daging mengandung arti tiga prinsip pernikahan Kristen. Pertama, monogamy heterosexual. Pernikahan Kristen adalah pernikahan sepadan, yaitu antara satu orang laki-laki dengan satu orang perempuan; yang keduanya memiliki kesetaraan dan tidak berada dalam posisi ordinasisubordinasi. Baik laki-laki maupun perempuan memiliki tingkat kesetaraan, sehingga pernikahan Kristen merupakan pernikahan yang saling mengakui keberadaannya masing-masing. ${ }^{40}$ Dengan demikian pernikahan ini adalah pernikahan sepadan dan saling melengkapi. Kedua, meninggalkan ayahnya dan ibunya. Pernikahan bukan berarti putusnya relasi dengan orang tua, melainkan membentuk lembaga baru tanpa intervensi kedua orang tua. Allah yang menjadi pemimpin dalam kehidupan rumah tangga yang baru. Ketiga, pernikahan berlangsung seumur hidup sampai maut memisahkan. Keempat, pernikahan memenuhi kebutuhan seksual laki-laki dan perempuan. Hanya dalam ikatan pernikahan kudus, hubungan seksual di ijinkan.

Pernikahan Kristen memiliki beberapa tujuan. Pertama secara teologis, tujuan pernikahan Kristen adalah memenuhi rencana Allah dalam ikatan pernikahan kudus. Kedua secara psikologis, pernikahan memenuhi tiga

${ }^{37}$ Dale Mathis dan Susan Mathis, Menuju Pernikahan Yang Sehat Dan Solid. (Yogyakarta: Andi Offset,2014), 12

${ }^{38}$ Charles R. Swindoll., Pernikahan: Sebuah Surga Dunia. (Jakarta: Methanoia Publishing, 2010), 34 .

${ }^{39}$ Jonathan A. Trisna. Pernikahan Kristen. Suatu Usaha Dalam Kristus. (Jakrta: Pendidikan Theologia Bethel Jakarta,1986), 1.

${ }^{40}$ Firman Panjaitan, "Kekerasan Terhadap Istri dalam Lingkup Domestik (Suatu Tinjauan Etis Kristiani tentang Kekerasan Terhadap Keluarga", Fidei: Jurnal Teologi Sistematika dan Praktika, Vol. 1, No. 1, Juli 2018, 56-60. 
kesatuan, yaitu kesatuan roh, jiwa dan tubuh. Secara sosiologi, pernikahan Kristen membentuk keluarga yang bersaksi ditengah masyarakat. Anak yang lahir dalam ikatan pernikahan yang sah dapat memenuhi kebutuhan anak untuk diterima dan diakui ditengah masyarakat. ${ }^{41}$ Selain itu, pernikahan juga bertujuan untuk membangun sebuah relasi yang saling menguatkan dan menolong dalam tantangan hidup setiap hari. ${ }^{42}$

Langkah-langkah menemukan dan memilih pasangan hidup yang sesuai dengan kehendak Tuhan adalah pertama, mendoakan. Kedua, memperhatikan kehendak Tuhan. Tuhan menghendaki seorang yang sudah lahir baru, berbeda lawan jenis, bertumbuh rohaninya, memiliki tujuan hidup, masih "sendirian", saling mencintai dan memperhatikan umur serta perhatikan nasehat orang tua. Ketiga, menyatakan cinta dengan jelas, sopan, bijaksana dan penuh hormat. Jangan langsung menuntut jawaban ya atau tidak. Jangan mengancam, nantikan jawabannya dengan sabar. Keempat, memberitahukan kepada orang tua jika sudah berkomitmen untuk berpacaran. ${ }^{43}$

\begin{tabular}{llllllllllll}
\hline $\mathbf{N o}$ & $\mathbf{S T}$ & $\mathbf{B G}$ & $\mathbf{P H}$ & $\mathbf{N O}$ & $\mathbf{S T}$ & $\mathbf{B G}$ & $\mathbf{P H}$ & $\mathbf{N O}$ & $\mathbf{S T}$ & $\mathbf{B G}$ & $\mathbf{P H}$ \\
$\mathbf{1}$ & 18 & 27 & 27 & $\mathbf{5 1}$ & 24 & 28 & 28 & $\mathbf{1 0 0}$ & 17 & 21 & 25 \\
$\mathbf{2}$ & 20 & 30 & 25 & $\mathbf{5 2}$ & 25 & 27 & 30 & $\mathbf{1 0 1}$ & 28 & 30 & 29 \\
$\mathbf{3}$ & 24 & 24 & 27 & $\mathbf{5 3}$ & 17 & 21 & 23 & $\mathbf{1 0 2}$ & 28 & 28 & 28 \\
$\mathbf{4}$ & 20 & 23 & 30 & $\mathbf{5 4}$ & 28 & 25 & 25 & $\mathbf{1 0 3}$ & 18 & 24 & 28 \\
$\mathbf{5}$ & 21 & 23 & 26 & $\mathbf{5 5}$ & 24 & 25 & 25 & $\mathbf{1 0 4}$ & 24 & 30 & 26 \\
$\mathbf{6}$ & 21 & 28 & 24 & $\mathbf{5 6}$ & 25 & 24 & 30 & $\mathbf{1 0 5}$ & 26 & 27 & 28 \\
$\mathbf{7}$ & 29 & 26 & 27 & $\mathbf{5 7}$ & 21 & 27 & 26 & $\mathbf{1 0 6}$ & 23 & 28 & 28 \\
$\mathbf{8}$ & 20 & 27 & 22 & $\mathbf{5 8}$ & 17 & 25 & 27 & $\mathbf{1 0 7}$ & 22 & 23 & 22 \\
$\mathbf{9}$ & 22 & 27 & 29 & $\mathbf{5 9}$ & 25 & 30 & 27 & $\mathbf{1 0 8}$ & 21 & 21 & 22 \\
$\mathbf{1 0}$ & 22 & 25 & 23 & $\mathbf{6 0}$ & 19 & 28 & 29 & $\mathbf{1 0 9}$ & 24 & 26 & 28 \\
$\mathbf{1 1}$ & 23 & 25 & 25 & $\mathbf{6 1}$ & 20 & 25 & 25 & $\mathbf{1 1 0}$ & 23 & 26 & 26 \\
$\mathbf{1 2}$ & 22 & 28 & 26 & $\mathbf{6 2}$ & 18 & 28 & 29 & $\mathbf{1 1 1}$ & 24 & 24 & 29
\end{tabular}

${ }^{41}$ Soleman Kawangmani, Pasangan Hidup. (Surakarta: PMK Surakarta, t.t), 1.

${ }^{42}$ Pondsius dan Susanna Takaliuang. Aku Cinta Padamu. Cara Memilih Pasangan Hidup Sesuai Dengan Kehendak Allah. (t.p., 1990), 58.

${ }^{43}$ Bahan Training PMK Surakarta. 
Pengaruh Saat Teduh... (Efi N., Daniel F. P)

\begin{tabular}{|c|c|c|c|c|c|c|c|c|c|c|c|}
\hline 13 & 22 & 27 & 29 & 63 & 22 & 19 & 28 & 112 & 30 & 26 & 26 \\
\hline 14 & 15 & 25 & 27 & 64 & 24 & 25 & 24 & 113 & 21 & 27 & 25 \\
\hline 15 & 15 & 27 & 29 & 65 & 22 & 23 & 24 & 114 & 22 & 24 & 23 \\
\hline 16 & 28 & 30 & 30 & 66 & 23 & 30 & 27 & 115 & 22 & 23 & 25 \\
\hline 17 & 25 & 30 & 28 & 67 & 27 & 27 & 30 & 116 & 29 & 29 & 28 \\
\hline 18 & 24 & 26 & 24 & 68 & 20 & 23 & 29 & 117 & 24 & 25 & 28 \\
\hline 19 & 19 & 25 & 27 & 69 & 24 & 28 & 27 & 118 & 22 & 27 & 29 \\
\hline 20 & 23 & 25 & 29 & 70 & 22 & 28 & 29 & 119 & 18 & 26 & 27 \\
\hline 21 & 16 & 23 & 27 & 71 & 24 & 29 & 26 & 120 & 16 & 25 & 27 \\
\hline 22 & 22 & 22 & 25 & 72 & 19 & 23 & 20 & 121 & 18 & 27 & 26 \\
\hline 23 & 16 & 22 & 25 & 73 & 23 & 24 & 24 & 122 & 16 & 24 & 26 \\
\hline 24 & 20 & 28 & 26 & 74 & 28 & 24 & 29 & 123 & 27 & 25 & 29 \\
\hline 25 & 18 & 23 & 25 & 75 & 22 & 27 & 28 & 124 & 19 & 23 & 24 \\
\hline 26 & 26 & 26 & 26 & 76 & 12 & 28 & 26 & 125 & 20 & 25 & 30 \\
\hline 27 & 20 & 26 & 27 & 77 & 19 & 24 & 28 & 126 & 21 & 26 & 27 \\
\hline 28 & 18 & 20 & 21 & 78 & 26 & 21 & 28 & 127 & 22 & 26 & 24 \\
\hline 29 & 30 & 26 & 26 & 79 & 21 & 24 & 26 & 128 & 19 & 26 & 25 \\
\hline 30 & 21 & 27 & 29 & 80 & 15 & 23 & 29 & 129 & 20 & 24 & 29 \\
\hline 31 & 26 & 27 & 29 & 81 & 23 & 27 & 29 & 130 & 19 & 24 & 25 \\
\hline 32 & 27 & 29 & 29 & 82 & 21 & 26 & 28 & 131 & 26 & 26 & 28 \\
\hline 33 & 24 & 30 & 30 & 83 & 14 & 20 & 24 & 132 & 22 & 20 & 20 \\
\hline 34 & 20 & 25 & 27 & 84 & 18 & 22 & 27 & 133 & 30 & 27 & 30 \\
\hline 35 & 22 & 25 & 28 & 85 & 18 & 25 & 23 & 134 & 24 & 27 & 30 \\
\hline 36 & 24 & 25 & 27 & 86 & 21 & 29 & 27 & 135 & 16 & 28 & 26 \\
\hline 37 & 20 & 24 & 24 & 87 & 27 & 26 & 28 & 136 & 21 & 25 & 24 \\
\hline 38 & 15 & 26 & 22 & 88 & 14 & 20 & 24 & 137 & 23 & 28 & 26 \\
\hline 39 & 21 & 23 & 24 & 89 & 22 & 24 & 24 & 138 & 21 & 25 & 24 \\
\hline 40 & 22 & 28 & 29 & 90 & 25 & 30 & 29 & 139 & 19 & 28 & 27 \\
\hline
\end{tabular}




\begin{tabular}{llllllllllll}
\hline $\mathbf{4 1}$ & 26 & 28 & 30 & $\mathbf{9 1}$ & 19 & 27 & 27 & $\mathbf{1 4 0}$ & 20 & 21 & 27 \\
$\mathbf{4 2}$ & 23 & 26 & 29 & $\mathbf{9 2}$ & 24 & 24 & 28 & $\mathbf{1 4 1}$ & 9 & 27 & 29 \\
$\mathbf{4 3}$ & 18 & 25 & 28 & $\mathbf{9 3}$ & 23 & 25 & 28 & $\mathbf{1 4 2}$ & 26 & 28 & 30 \\
$\mathbf{4 4}$ & 18 & 23 & 25 & $\mathbf{9 4}$ & 14 & 26 & 25 & $\mathbf{1 4 3}$ & 30 & 30 & 28 \\
$\mathbf{4 5}$ & 19 & 27 & 30 & $\mathbf{9 5}$ & 25 & 28 & 30 & $\mathbf{1 4 4}$ & 27 & 27 & 28 \\
$\mathbf{4 6}$ & 21 & 25 & 27 & $\mathbf{9 6}$ & 19 & 26 & 24 & $\mathbf{1 4 5}$ & 19 & 23 & 22 \\
$\mathbf{4 7}$ & 16 & 28 & 28 & $\mathbf{9 7}$ & 20 & 27 & 26 & $\mathbf{1 4 6}$ & 28 & 24 & 25 \\
$\mathbf{4 8}$ & 23 & 27 & 26 & $\mathbf{9 8}$ & 20 & 28 & 30 & $\mathbf{1 4 7}$ & 24 & 25 & 30 \\
$\mathbf{4 9}$ & 20 & 22 & 21 & $\mathbf{9 9}$ & 14 & 24 & 22 & $\mathbf{1 4 8}$ & 24 & 25 & 30 \\
$\mathbf{5 0}$ & 20 & 20 & 24 & $\mathbf{1 0 0}$ & 18 & 25 & 24 & $\mathbf{1 4 9}$ & 22 & 25 & 24 \\
\hline
\end{tabular}

Tabel 1. Data skala kuesioner

*ST =saat teduh, ${ }^{*}$ BG= Beribadah di Gereja, ${ }^{*} \mathrm{PH}=$ Pasangan Hidup

Penelitian dilakukan pada bulan mei-juni 2019 dengan sasaran mahasiswa Kristen se-Surakarta. Proses penelitian dilakukan dengan pembuatan instrumen dengan tiga variabel dan di dapatkan 48 butir pernyataan. Istrumen diujikan secara terbatas kepada 10 responden untuk uji validasi dan reliabilitas. Uji validasi instrumen di dapatkan minimal 6 butir pernyataan yang bertahan pada variabel beribadah di Gereja sehingga instrumen di susun ulang sehingga mendapatkan 6 butir petnyataan setiap aspeknya. Uji Reliabilitas juga menunjukan bahwa data yang didapatkan dari instrumen ajeg/reliabel.

Hasil data yang telah dianalisis didapatkan dari instrumen yang telah diuji validitasi dan reabilitasnya. Aspek-aspek pertanyaan dari variabel-variabel ini dapat diteruskan untuk penelitian yang mendatang. Variabel dalam penelitian ini adalah variabel saat teduh, variabel beribadah di Gereja dan variabel keputusan dalam memilih pasangan hidup. Total terdapat 16 pernyataan sebagai instrumen pengumpulan data pada penelitian ini dengan menggunakan skala linkert.

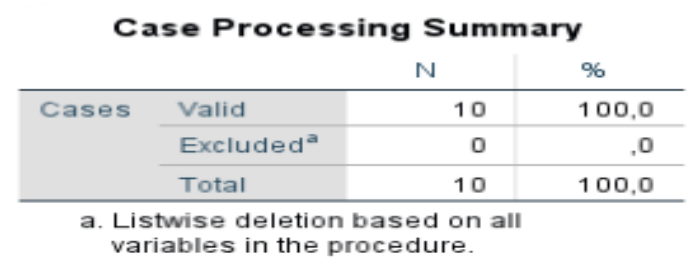

Tabel 2. Hasil SPPS uji Reliabilitas 
Instrumen pernyataan berisi 18 pertanyaan disebar kepada seluruh mahasiswa di Surakarta. 150 mahasiswa memberikan tanggapan terhadap instrumen tersebut seperti yang terlihat pada tabel 1.1. Data yang di dapat kemudian dilakukan uji persyaratan yaitu uji normalitas dan uji variansi. Berdasarkan uji normalitas data tersebar secara homogen. Variansi data antara beribadah gereja dan PH menunjukan homogen, sedangka saat teduh terhadap PH terdapat signifikansi.

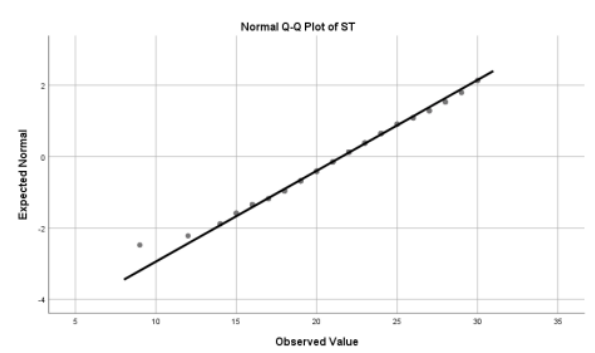

Gambar1. uji normalitas data saat teduh

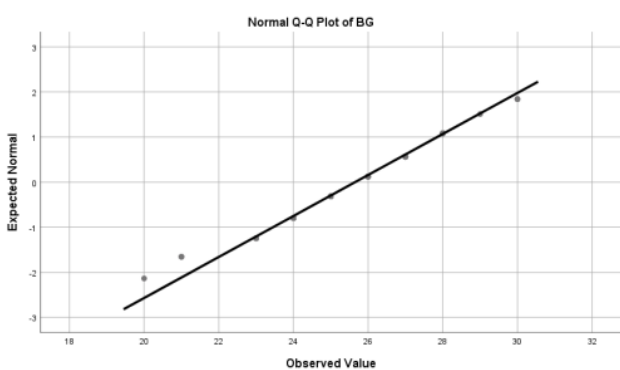

Gambar 2. uji normalitas data beribadah di gereja

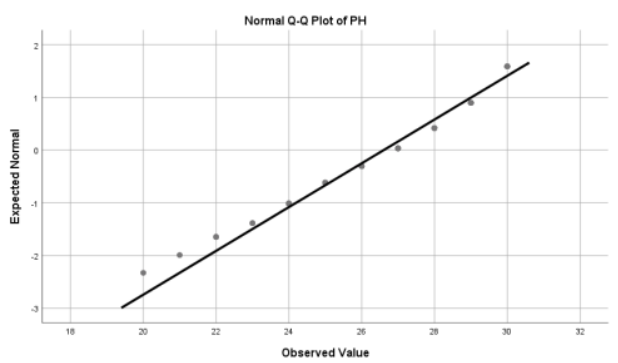

Gambar 3. uji normalitas data

Analisis yang pertama dilakukan adalah untuk mengetahui pengaruh saat teduh terhadap pengambilan keputusan pasngan hidup. Analis dilakukan dengan uji korelasi dan di dapatkan hasil p-value 0,000 yang lebih kecil daripada 0,05 yang berarti bahwa terdapat hubungan positif antara kedua variabel tersebut. Analisis lanjutan dilakukan dengan menggunakan uji regresi dan didapatkan hasil p-value 0,000 yang berarti berpengaruh signifikan. Pengaruh tersebut dirumuskan dalam koefien $Y=22,446+0,193 X$. Berdasarkan hal ini saat teduh memiliki pengaruh dalam pengambilan keputusan pasangan hidup. 


\begin{tabular}{|c|c|c|c|c|c|c|}
\hline \multicolumn{7}{|c|}{ ANOVA $^{a}$} \\
\hline Model & & $\begin{array}{l}\text { Sum of } \\
\text { Squares }\end{array}$ & df & Mean Square & $\mathrm{F}$ & Sig. \\
\hline \multirow[t]{3}{*}{1} & Regression & 85,691 & 1 & 85,691 & 16,299 & $.000^{\mathrm{b}}$ \\
\hline & Residual & 778,102 & 148 & 5,257 & & \\
\hline & Total & 863,793 & 149 & & & \\
\hline
\end{tabular}

Tabel 3. Uji Regresi saat teduh terhadap pengambilan keputusan pasangan hidup Analisis kedua dilakukan untuk mengetahui pengaruh beribadah di gereja terhadap pengambilan keputusan pasangan hidup. Analisis dilakukan dengan uji korelasi dan di dapatkan hasil p-value 0,000 yang lebih kecil daripada 0,05 yang berati bahwa terdapat hubungan positif antara kedua variabel tersebut. Melihat hasil tersebut kemudian dilakukan uji lanjutan yaitu uji regresi dan didapatkan hasil $p$-value 0,000 bahwa ada pengaruh yang signifikan. Pengaruh tersebut dirumuskan dalam koefisien $\mathrm{Y}=15,311+0,442 \mathrm{X}$. Analisis kedua didapatkan hasil bahwa beribadah di gereja memberikan pengaruh dalam pengambilan keputusan pasangan hidup.

\begin{tabular}{|c|c|c|c|c|c|c|}
\hline \multicolumn{7}{|c|}{ ANOVA $^{a}$} \\
\hline Model & & $\begin{array}{l}\text { Sum of } \\
\text { Squares }\end{array}$ & $\mathrm{df}$ & Mean Square & $\mathrm{F}$ & Sig. \\
\hline \multirow[t]{3}{*}{1} & Regression & 177,807 & 1 & 177,807 & 38,361 &, $000^{\circ}$ \\
\hline & Residual & 685,986 & 148 & 4,635 & & \\
\hline & Total & 863,793 & 149 & & & \\
\hline
\end{tabular}

Tabel 4. Uji Regresi beribadah di gereja terhadp pengambilan keputusan pasangan hidup

Analisis ketiga dilakukan dengan untuk mengetahui pengaruh variabel saat teduh dan beribadah di gereja terhadap pengambilan keputusan pasangan hidup. Analisis dilakukan dengan uji regresi ganda dengan dua prediktor. Hasil dari analisis ini didapatkan hasil p-value 0.000 lebih kecil dari 0,05 yang berati memberikan pengaruh signifikan. Pengaruh tersebut dirumuskan $Y=14,329+$ $0,383 \mathrm{X}_{1}+0,116 \mathrm{X}_{2}$. Berdasarkan hal ini dapat saat teduh dan beribadah di gereja memberikan pengaruh yang signifikan terhadap pengambilan keputusan pasangan hidup kristen. 
ANOVA $^{\mathrm{a}}$

\begin{tabular}{|c|c|c|c|c|c|c|}
\hline Model & & $\begin{array}{l}\text { Sum of } \\
\text { Squares }\end{array}$ & df & Mean Square & $\mathrm{F}$ & Sig. \\
\hline \multirow[t]{3}{*}{1} & Regression & 205,357 & 2 & 102,679 & 22,924 &, $000^{\mathrm{b}}$ \\
\hline & Residual & 658,436 & 147 & 4,479 & & \\
\hline & Total & 863,793 & 149 & & & \\
\hline
\end{tabular}

a. Dependent Variable: $\mathrm{PH}$

b. Predictors: (Constant), ST, BG

Tabel 5. Uji Regresi ganda saat teduh dan beribadah di gereja terhadap pengambilan keputusan pasangan hidup

Saat teduh dan beribadah di Gereja memiliki hubungungan yang positif dan mempengaruhi pengambilan keputusan dalam memilih pasangan hidup. Melihat tren positif dari dua variabel ini perlu diadakan pengembanganpengembangaan untuk terus mengerjakan saat teduh dan ibadah di Gereja sesuai konteks saat ini. Pengembangan mengenai saat teduh dapat dilaukan secara intensif pada persekutuan-perskutuan, ibadah, sharing dan kelompok pemuridan sehingga mahasiswa kristen di Surakarta memiliki gaya hidup untuk melakukan saat teduh. Pengembangan ibadah-ibadah di Gereja juga harus menjawab kebutuhan mahasiswa pada masa sekarang dan perlu juga menyinggung topiktopik khusus mengenai pembinaan warga jemaat terkhusus hubungan pacaran dan pemilihan pasangan hidup. Ibadah Gereja harus interaktif, menarik, dan inovatif sehingga kesan ibadah gereja bukan lagi ibadah yang menjemukan akan tetapi ibadah yang penuh ajaran kebenaran Firman Tuhan salah satunya adalah untuk memberi petunjuk bagi para mahasiswa dalam mengambil keputusan dalam memilih pasangan hidup.

Pengambilan keputusan dalam memilih pasangan hidup yang tepat akan sangat menentukan masa depan kehidupan mahasiswa. Mahasiswa secara visioner dapat mewujudkan shalom di bumi ini dengan dapat mewujudkan bakal-bakal keluarga Kristen yang berbuah, menjadi berkat, tidak ada kekerasan dalam rumah tangga, dan tidak terjadi perceraian. Kedua variabel ini sangat penting dalam kaitannya dalam pengambilan keputusan dalam memilih pasangan hidup bagi mahasiswa Kristen pada masa sekarang.

Hasil penelitian ini menjadi hal yang penting bagi Gereja-gereja Tuhan pada masa kini dan lembaga-lembaga pelayanan dalam membina pertumbuhan iman remaja yang merupakan usia mahasiswa pada masa kini. Pertumbuhan iman yang didasarkan dari saat teduh dan beribadah di gereja telah terbukti bahwa dua variabel tersebut sangat berpengaruh terhadap pengambilan keputusan dalam memilih pasangan hidup. Sumbangsih Gereja-gereja Tuhan dan lembaga-lembaga pelayanan dalam membina pertumbuhan iman melalui 
saat teduh dan beribadah di Gerja diharapkan dapat mengurangi kasus-kasus rumah tangga yang terjadi dikarenakan dari masa mahasiswa, para mahasiswa sudah dapat bertanggung jawab dalam mengambil keputusan dalam memilih pasangan hidup. Pada akhirnya shalom terwujud dalam keluarga Kristen dan terus berimbas terciptanya shalom bagi bangsa Indonesia.

Penelitian-penelitan pengembangan lanjutan mengenai dua variabel independen pada penelitian ini perlu dilakukan terkait generasi yang dinamis akibat adanya perubahan zaman. Generasi-generasi yang terpapar akan perubahan zaman akan memiliki kebutuhan dan karakter yang unik menyesuaikan dengan zamannya. Gereja dan Lembaga pelayanan perlu melakukan pengembangan untuk terciptanya shalom di Indonesia yang diawali dari keluarga-keluarga Kristen.

\section{Kesimpulan}

Berdasarkan hasil dan pembahasan dari penelitian ini didapatkan kesimpulan yaitu: pertama, saat teduh memiliki pengaruh yang signifikan terhadap pengambilan keputusan Pasangan Hidup dengan koefisien $Y=22,446+$ 0,193X. Kedua Beribadah di Gereja memiliki peraguh yang signifikan terhadap pengambilan keputusan Pasangan Hidup dengan koefisien $\mathrm{Y}=15,311+0,442 \mathrm{X}$. Ketiga, Saat Teduh dan Beribadah di Gereja memiliki pengaruh yang signifikan terhadap pengambilan keputusan Pasangan Hidup dengan koefisien $Y=14,329+$ $0,383 \mathrm{X}_{1}+0,116 \mathrm{X}_{2}$.

Saran dari penelitian ini adalah melihat dari pengaruh Saat Teduh dan Beribadah di gereja terhadap pengambilan keputusan Pasangan hidup maka saran yang kami berikan adalah pertama, gereja Tuhan dan Persekutuan Mahasiswa Kristen perlu mengadakan pelatihan dan lokakarya saat teduh bagi mahasiswa Kristen yang sesuai konteks masa kini. Kedua, Gereja perlu mendesain materi dan bentuk ibadah yang berkualitas dan sesuai dengan kebutuhan mahasiswa Kristen. Ketiga perlu di lakukan penelitian model saat teduh dan ibadah di gereja yang sesuai dengan generasi mahasiswa pada masa kini sehingga setiap pengambilan keputusan mengenai pasangan hidup tepat sesuai dengan prinsip kebenaran Firman Tuhan. 


\section{Daftar Kepustakaan}

Brunner, Peter; Worship in the Name of Jesus. Diterjemahkan oleh M.H. Bertram Louis: Concordia, 1968.

Goleman. Daniel; Kecerdasan Emosional untuk mencapai Puncak Prestasi, Jakarta:PT Gramedia, 2001.

Handoyo, Enrico Darmawan; "Pembuatan Aplikasi Saat Teduh "Makanan Rohani" di Windows 8 Metro"Haryono, Timotius., "Saat Teduh", Bahan Ceramah Pada Persekutuan Mahasiswa Kristen Surakarta, t.t

Haryono, Timotius; dan Daniel Fajar Panuntun, “Andil Pemuridan Kontekstual

Yesus Kepada Petrus Yakobus Dan Yohanes Terhadap Keterbukaan Konseling Mahasiswa Pada Masa Kini”, Jurnal Gamaliel:Teologi Praktika, Vol 1, No 1, 2019.

Haryono, Timotius., "Saat Teduh", Bahan Ceramah Pada Persekutuan

Mahasiswa Kristen Surakarta, t.t

Haryono, Timotius, Saved By Faith, Surakarta: Yayasan Gamaliel, 2015.

Haryono, Timotius; Wawancara dengan pakar: Pembina pelayanan PMK

Surakarta, Surakarta, 2019.

Hoon, Paul W., The Integrity of Worship, Nashvile: Abingdon Press, 1971.

Jusri, "Peranan Polri dalam menangai kasus kekerasan Rumah Tangga di Kota Bau Bau", Jurnal Sosio Sains, Vol 4, No 9, 2015.

Kawangmani, Soleman., "Memilih Pasangan Hidup". Bahan Ceramah Pada Persekutuan Mahasiswa Kristen Surakarta, t.t.

Kawangmani, Soleman, Pasangan Hidup.Surakarta: PMK Surakarta, t.t.

Lumintang, Stevri Indra; dan Danik Astuti Lumintang, Theologia penelitian dan

Penelitian Theologis science-ascience serta metodologinya,Jakarta: Geneva Insani Indonesia, 2016.

Luni, Tumanan, Yohanis; "Ibadah Kontemporer: Sebuah Analisis Reflektif Terhadap Hadirnya Budaya Populer Dalam Gereja Masa Kini," Jurnal Jaffray, Vol 13, No 1, 2015.

Mathis, Dale; dan Susan Mathis, Menuju Pernikahan Yang Sehat Dan Solid. Yogyakarta: Andi Offset2014.

Mikha Agus Widiyanto, Statistika: Untuk Penelitian Bidang Teologi, Pendidikan, Agama Kristen, dan Pelayanan Gereja. Bandung: Kalam Hidup,2014.

Nusyur,Raihan; "Jurnalisme Damai dalam Pemberitaan PembakaranGereja di Aceh SIngkil pada Harian Waspada," Jurnal Komunikasi Global, Vol. 6, No 1, 2017. 
Notopuro, Timothy Tiovano; Alexander Setiawan, Justinus Andjarwirawan, "Pembuatan Aplikasi Saat Teduh Pada Mobile Device Berbasis Android," Jurnal Infra, Vol 4, No 2, 2016; 1

Panjaitan, Firman, "Kekerasan Terhadap Istri dalam Lingkup Domestik (Suatu Tinjauan Etis Kristiani tentang Kekerasan Terhadap Keluarga", Fidei: Jurnal Teologi Sistematika dan Praktika, Vol. 1, No. 1, Juli 2018.

Panjaitan, Firman \& Marthin S. Lumingkewas, "Ibadah Jemaat Kristen Kontemporer Abad 21 dan Tinjauan Kritis-Liturgis, Fidei: Jurnal Teologi Sistematikan dan Praktika, Vo. 2, No. 1, Juni 2019.

Salirawati, Das; Antuni WIyarsi, dan Eddy Sulistyowati, "Survei Terhadap Terjadinya Kekerasan dalamRumah Tangga (KDRT) Wanita Karier di Daerah Istimewa Yogyakarta", Jurnal Penelitian Humaniora, Vol 1, No 1, 2013.

Schnase, Rober; 5 Ciri Jemaat yang Bertumbuh, Malang:Gandum Mas,2016.

Septarina, Sri Wahyuning; dan Giovanni, "Perancangan Buku Saat Teduh "Be

Strong" Sebagai Sarana Pertumbuhan Rohani Bagi Anak-Anak", Jurnal Ruparupa, Vol 4, No 1, 2015.

Siringoringo, Artarty; "Etnografi komunikasi dalam ibadah sekolah minggu

Huria kristen Batak Protestan (HKBP) Maranatha kecamatan Payung Sekaki,” Jom Fisip, Vol 2 No 2, 2015.

Sitanggang, Urni Hermawaty; "Bahasa lidah dalam Ibadah bersama berdasarkan

1 Korintus 14", Dunamis (Jurnal Teologi dan Pendidikan Kristen), Vol 2, No 1, 2017.

Surur, Achmad Tubagus dan Hanik Rosyidah, "Perceraian Dini: Studi Terhadap Putusan Pengadilan Agama Pekalongan", Jurnal Hukum Islam, Vol 14, No $1,2016$.

Swindoll, Charles R., Pernikahan: Sebuah Surga Dunia. Jakarta: Methanoia Publishing2010.

Takaliuang, Pondsius; dan Susanna Aku Cinta Padamu. Cara Memilih Pasangan Hidup Sesuai Dengan Kehendak Allah. t.p., 1990.

Thuhumury, Nelly P., Strategi Pemulihan Gereja, Tangerang, Mantana Publishing Utama, 2015.

Trisna, Jonathan A., Pernikahan Kristen. Suatu Usaha Dalam Kristus.Jakrta: Pendidikan Theologia Bethel Jakarta, 1986.

William Yount R, Research Deseign and Statistical Analysis in Christian Ministry. Fort Worth: Southwestern Baptis Teological Swminary, 1999.. White, James F., Pengatar Ibadah Kristen,Jakarta: BPK Gunung Mulia,2017. 
Pengaruh Saat Teduh... (Efi N., Daniel F. P)

Whitney, Donald S., 10 Pilar Penopang Kehidupan Kristen. Malang: Lembaga Literatur Baptis, 199.

Yusra, Dhony; "Perceraian dan Akibatnya: Kajian Tentang Pengajuan Permohonan Cerai yang diajukan Pegawai Negeri Sipil”, Lex Jurnalica, Vol 2, No 3, 2005. 